\title{
A HUZALELEKTRÓDÁS AKTÍV VÉDŐGÁZOS ÍVHEGESZTÉS KORSZERÜ ELJÁRÁSVÁLTOZATAINAK ÖSSZEHASONLÍTÁSA VARRATGEOMETRIA ALAPJÁN
}

\author{
Németh Alexandra \\ adjunktus, Anyagszerkezettani és Anyagtechnológiai Intézet \\ 3515 Miskolc, Miskolc-Egyetemváros, e-mail: metnak@uni-miskolc.hu
}

\begin{abstract}
Absztrakt
Jelen munkában bemutatom azokat az eredményeket, amelyeket tömör huzalelektródás, aktív védögázos ivhegesztés esetén különbözö impulzus-üzemmódok (impulzusos, duplaimpulzusos) valamint a hegesztési paraméterek varratalak befolyásoló tényezök hatásának vizsgálatával nyertünk. A vizsgálatok során két különbözö hegesztögépet használtunk. Mindkét berendezésen a lehetöségekhez mérten azonos anyagátmeneteket választottunk ki és vizsgáltuk meg azok hatását a varratalakra. A hegesztendö alapanyag, a hozaganyag és az alkalmazott védögázkeverék minden esetben azonos volt. Feltártuk a kapcsolatot az üzemmódok, a hegesztési paraméterek és a varratgeometria jellemzők (külsö és belső formatényezö, beolvadási mélység, varratszélesség) között.
\end{abstract}

Kulcsszavak: huzalelektródás aktív védőgázos ivhegesztés, anyagátviteli mód, hegesztési paraméterek, impulzustechnika, varratgeometria/beolvadási alak

\begin{abstract}
In the present work I present the results obtained by investigating the influence of different pulse modes (pulse, double pulse) and the welding parameters in case of gas metal arc welding. Two different welding machines were used in the tests. In both devices, the same material transitions were selected as far as possible and their effect on the joint was investigated. The base material, the filler material and the gas mixture were same in every case. The relationship between metal transfer modes, welding parameters and weld geometry characteristics (external and internal form factor, melt depth, weld width) has been revealed.
\end{abstract}

Keywords: GMAW, metal transfer mode, welding parameters, pulsed technology, weld geometry/shape

\section{Bevezetés}

Napjaink egyik legelterjedtebb ívhegesztő eljárása acélszerkezetek esetén a huzalelektródás védőgázos ívhegesztés. Ez az eljárás jó ívstabilitással bír, az elkészült varrat beolvadási mélysége ugyancsak megfelelő, leolvasztási teljesítménye nagy, egyszerüen kezelhető és megbízható. Az elmúlt évtizedekben számos hegesztőgép gyártó fejlesztett ki olyan eljárásváltozásokat, amelyek egyaránt könnyíthetik a munkavégzést és növelhetik a termelékenységet.

A korszerü hegesztési eljárásváltozatok nagymértékü lehetőséget biztosítanak számunkra a minőségi és termelékenységi javulásokban, többféle megoldásváltozatból tudjuk kiválasztani számunkra a legkedvezőbbet, amelyet az eljárások kiváló szabályozásának lehetőségével az adott munkához tudjuk igazítani. Különféle határértékek között finomhangolásokra adnak lehetőséget a változásokra rendkívül gyorsan reagálni képes modern, mikroprocesszor vezérelt áramforrások, így 
olyan technológiai megvalósítások is lehetségessé váltak, amelyek korábban nem álltak rendelkezésre. Így egyre inkább elterjednek az egyedi ívtípusok és anyagátmenet, ilyen például a kettősimpulzus.

Ezek az eljárásváltozatok nagyobb leolvasztási teljesítményt, biztosabb beolvadást garantálhatnak adott lemezvastagság esetén, valamint csökkenthetik az utómegmunkálás és a varratjavítások szükségességét, ezáltal gazdaságosabbá tehetik a gyártást. Szem előtt kell továbbá azt is tartani, hogy bizonyos alapanyagok, speciális hegesztéstechnológiát követelnek meg, amelyeknek az egyik követelménye lehet a höbevitel csökkentése vagy szük keretek között való tartása.

$\mathrm{Az}$ alábbi ábra példát szemléltet a stabil ív tartományát ívhegesztésnél $82 \% \mathrm{Ar}+18 \% \mathrm{CO}_{2}$ védőgáz keverék alkalmazása mellett.

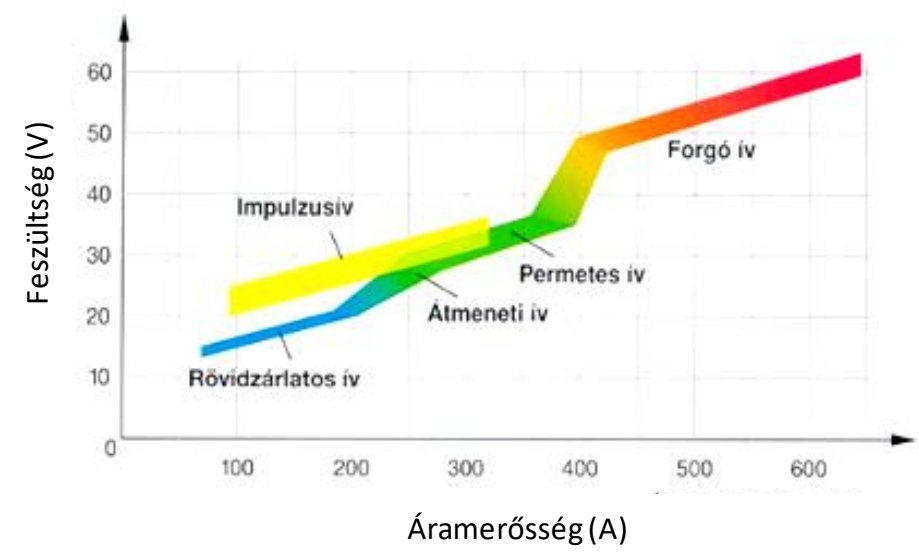

1. ábra. Hagyományos ívtípusok, anyagátviteli módok stabil munkatartománya 1,2 mm-es huzalelektródára, kevert védögáz esetére [2]

A diagram bal alsó szakaszán látható (kék terület), a rövidzárlatos anyagátvitel kis áramerősségnél és feszültségnél jön létre. Ebben az esetben a huzalvég periodikusan, másodpercenként többször beleér a hegfürdőbe és rövidzárlatot okoz. Ezt az anyagátviteli módot használjuk például gyöksorok elkészítéséhez is. Az áramerősséget és a feszültséget tovább növeljük, a huzal átméröjénél nagyobb cseppek válhatnak le, ezt nevezzük durvacseppes anyagátvitelnek. Ennek hátránya, hogy nagymértékü fröcsköléssel járhat, a beolvadás viszont jobb, mint impulzusíves anyagátvitel esetében. Nagyobb feszültség és áramerősség esetén létrejön az ún. permetes ív (finomcseppes anyagátmenet, zöld terület), amely esetén a cseppméret már kisebb, mint a huzalelektróda átméröje. A beolvadási mélység ebben az esetben nagy, akárcsak a leolvasztási teljesítmény, valamint a hőbevitel. Fontos megemlíteni a szinergikus programok jelentőségét, amelyek fröcskölés-mentes anyagátmenetet garantálnak kis höbevitellel és füstképződéssel [1-5].

\section{Vizsgálati terv}

Munkánk során többféle anyagátviteli módot (durvacseppes, rövidzárlatos, impulzusos, duplaimpulzusos) vizsgáltunk meg. Hegesztési kísérleteinkhez a Daihen Varstroj WB-P500L és a REHM MegaPuls 500 ívhegesztő gépet használtunk (Miskolci Egyetem, Anyagszerkezettani és Anyagtechnológiai Intézet). 
A kísérleteinkhez használt alapanyag S235JR anyagminőségü lemez volt, vastagsága $4 \mathrm{~mm}$. Az alkalmazott hozaganyag WDI $15 \mathrm{SG}$ típusú, átmérője $1,2 \mathrm{~mm}$. Az alapanyag és hozaganyag összetételét és mechanikai tulajdonságait az 1. és 2. táblázatok foglalják össze.

1. táblázat. A vizsgálat alapanyag kémiai összetétele max. tömeg\%-ban és mechanikai tulajdonságai (EN 10025-2:2004 szerint)

\begin{tabular}{|l|c|c|c|c|c|c|c|c|c|}
\hline & $\mathbf{C}(\boldsymbol{\%})$ & $\mathbf{M n}(\boldsymbol{\%})$ & $\mathbf{P}(\boldsymbol{\%})$ & $\mathbf{S}(\boldsymbol{\%})$ & $\mathbf{N}(\boldsymbol{\%})$ & $\mathbf{C u}(\boldsymbol{\%})$ & $\mathbf{R}_{\mathbf{p 0 . 2}}(\mathbf{M P a})$ & $\mathbf{R}_{\mathbf{m}}(\mathbf{M P a})$ & $\mathbf{A}_{\mathbf{5}}(\boldsymbol{\%})$ \\
\hline S235J & 0,17 & 1,4 & 0,04 & 0,04 & 0,012 & 0,55 & 235 & $360-510$ & 26 \\
\hline
\end{tabular}

2. táblázat. Az alkalmazott hozaganyag vegyi összetétele és mechanikai jellemzői

\begin{tabular}{|l|c|c|c|c|c|c|c|c|}
\hline \multicolumn{1}{|c|}{ Típus } & $\mathbf{C}(\boldsymbol{\%})$ & $\mathbf{S i}(\boldsymbol{\%})$ & $\begin{array}{c}\text { Mn } \\
(\boldsymbol{\%})\end{array}$ & $\mathbf{P}(\boldsymbol{\%})$ & $\mathbf{S}(\boldsymbol{\%})$ & $\begin{array}{c}\mathbf{R p}_{\mathbf{0} .2} \\
(\mathbf{M P a})\end{array}$ & $\begin{array}{c}\mathbf{R}_{\mathbf{m}} \\
(\mathbf{M P a})\end{array}$ & $\mathbf{A}_{\mathbf{5}}(\boldsymbol{\%})$ \\
\hline $\begin{array}{l}\text { WDI 15 SG } \\
\text { (MSZ EN ISO 14341:2011 G3Si1) }\end{array}$ & 0,078 & 0,85 & 1,46 & 0,025 & 0,025 & 470 & 560 & 26 \\
\hline
\end{tabular}

A védőgáz az MSZ EN ISO 14175 szabvány szerinti M21 (82 V\% Argon + 18 V\% CO $_{2}$ ) gázkeverék volt. A hozaganyag, a védőgáz és az alapanyag minden esetben azonos volt, így a vizsgálatok során kizártuk a gázkeverék varratalakot befolyásoló hatását.

3. táblázat. A kisérletek állandó és változó paraméterei

\begin{tabular}{cc}
\hline Állandó/közel állandó paraméterek & Vizsgálati paraméterek \\
\hline Alapanyag minősége, mérete és kezdeti hömérséklet & Beolvadási mélység \\
A pisztoly döntési szöge $\left(60-70^{\circ}\right)$ & Megömlesztett terület \\
Hegesztési sebesség $(250 \mathrm{~cm} / \mathrm{min})$ & Formatényező \\
Védőgáz mennyiség $(12-14 \mathrm{l} / \mathrm{min})$ & Hegesztési áramerösség \\
Huzalelőtolási sebesség $(6-9 \mathrm{~m} / \mathrm{min})$ & \\
Gázterelö kiömlő keresztmetszete & \\
\hline
\end{tabular}

Vizsgálataink során hernyóvarratokat készítettünk, rövidzárlatos, impulzusos, valamint duplaimpulzusos anyagátviteli módokkal (1. ábra első szakasza, I<200 A) PA hegesztési pozícióban. 12 darab vizsgálandó varrat készült $200 \mathrm{~mm}$-en hosszan, amelyek között $10 \mathrm{~mm}$ távolságot hagytunk ki.

4. táblázat. A kisérletek paraméterei

\begin{tabular}{ccllllll}
\hline Hegesztőgép gyártója & Sorszám & \multicolumn{1}{c}{ Jelölés } & Anyagátviteli mód & I (A) & U (V) & Szinergia \\
\hline \multirow{6}{*}{ Rehm } & 1. & R/120-RZ & rövidzárlatos & 120 & 21 & Bekapcsolva \\
& 2. & R/120-I & impulzus & 120 & 21 & Bekapcsolva \\
& 3. & R/120-DI & duplaimpulzus & 120 & 21 & Bekapcsolva \\
& 4. & R/170-RZ & durvacseppes & 170 & 25 & Bekapcsolva \\
& 5. & R/170-I & impulzus & 170 & 25 & Bekapcsolva \\
& 6. & R/170-DI & duplaimpulzus & 170 & 25 & Bekapcsolva \\
\hline
\end{tabular}




\begin{tabular}{cclllccc}
\hline Hegesztőgép gyártója & Sorszám & \multicolumn{1}{c}{ Jelölés } & Anyagátviteli mód & I (A) & U (V) & Szinergia \\
\hline \multirow{5}{*}{ Daihen } & 7. & D/170-RZ & durvacseppes & 170 & 17 & Bekapcsolva \\
& 8. & D/170-I & impulzus & 170 & 24 & Bekapcsolva \\
& 9. & D/170-DI & duplaimpulzus & 170 & 24 & Bekapcsolva \\
& 10. & D/150-DCS-ON & durvacseppes & 150 & 17 & Bekapcsolva \\
& 11. & D/150-DCS-OFF1 & durvacseppes & 150 & 22 & Kikapcsolva \\
& 12. & D/150-DCS-OFF2 & durvacseppes & 150 & 24 & Kikapcsolva \\
\hline
\end{tabular}

A hegesztés során a HKS P1000 folyamatfelügyelő rendszert is alkalmaztunk az áramerősség és az ívfeszültség változásának megfigyelésére.

\section{Eredmények}

Az elkészült kötéseket feldaraboltuk és minden egyes adott paraméterkombinációjú szakaszból 11 darab próbatestet munkáltunk ki a varrathernyó középső szakaszából, amikor már a hegesztési paraméterek állandósultak. A kimunkált próbatesteket ezt követően elkészítettük makrovizsgálatra. A marószer 2\%-os $\mathrm{HNO}_{3}$ oldat volt. A csiszolatokon elvégeztük a varratgeometria elemzését a Zeiss Obserever.D1m. optikai mikroszkóp segítségével, valamint meghatároztuk a varrat szélességét (b, $\mathrm{mm})$, beolvadási mélységét $\left(\mathrm{h}_{1}, \mathrm{~mm}\right)$ és a varratdudor magasságát $\left(\mathrm{h}_{2}, \mathrm{~mm}\right)$. Ezt követően kiszámoltuk a külső formatényezőt $(\varphi)$ az alábbi képlet segítségével:

$$
\varphi=b / h_{2} .
$$

Kiszámítottuk továbbá a belső formatényező $(\psi)$ értékét is:

$$
\psi=b / h_{1} \text {. }
$$

ahol: $\mathrm{a} \mathrm{h}_{1},(\mathrm{~mm})$ varrat beolvadási mélysége.

Az kristályosodási repedés kockázatának felmérésekor az alap- és hozaganyag összetételének vizsgálat után rögtön a varrat formája, vagyis belső geometriai tényezője a legfontosabb paraméter. A se nem túl nagy $(\psi>>2)$, se nem túl kicsi $(\psi<2)$ érték nem kedvező. Túl nagy formatényező esetén kis hatékonyságot, nagy varratközi hőmérséklet mellett szemcsedurvulást figyelhetünk meg, valamint káros kiválásokat. A gyakorlatban törekszünk a $\psi>2$ formatényezőjű varratok előállítására.

A varratok jellemző geometriai méreteit, valamint a külső és belső formatényező értékeit az alábbi táblázat foglalja össze.

\begin{tabular}{|c|c|c|c|c|c|c|c|c|c|}
\hline Jelölés & $\begin{array}{c}\text { Anyagátviteli } \\
\text { mód }\end{array}$ & $\begin{array}{c}I \\
(A)\end{array}$ & $\begin{array}{c}U \\
(V)\end{array}$ & $\begin{array}{l}t_{h}, \\
(s)\end{array}$ & $\begin{array}{c}b \\
(m m)\end{array}$ & $\begin{array}{c}h_{l}, \\
(m m)\end{array}$ & $\begin{array}{c}\boldsymbol{h}_{2} \\
(\boldsymbol{m m})\end{array}$ & $\psi$ & Szinergia \\
\hline$R / 120-R Z$ & rövidzárlatos & 120 & 21 & 25 & 6 & 2 & 3 & & Bekapcsolva \\
\hline$R / 120-I$ & impulzus & 120 & 21 & 28 & 9 & 2 & 3 & 4 & Bekapcsolva \\
\hline R/120-DI & duplaimpulzus & 120 & 21 & 45 & 12 & 1 & 3 & 4 & Bekapcsolva \\
\hline R/170-DCS & rövidzárlatos & 170 & 25 & 30 & 9 & 3 & 3 & 3 & Bekapcsolva \\
\hline
\end{tabular}

5. táblázat. A varratok makroszkópi csiszolaton mért geometriai méretei 
Huzalelektródás aktív védögázas ivhegesztés eljárásváltozatainak összehasonlitása

\begin{tabular}{|c|c|c|c|c|c|c|c|c|c|c|}
\hline Jelölés & $\begin{array}{c}\text { Anyagátviteli } \\
\text { mód }\end{array}$ & $\begin{array}{c}I \\
(A)\end{array}$ & $\begin{array}{c}U \\
(V)\end{array}$ & $\begin{array}{l}t_{h}, \\
(s)\end{array}$ & $\begin{array}{c}b \\
(\mathrm{~mm}) \\
\end{array}$ & $\begin{array}{c}h_{1}, \\
(\mathrm{~mm})\end{array}$ & $\begin{array}{c}h_{2}, \\
(\mathrm{~mm})\end{array}$ & $\psi$ & $\varphi$ & Szinergia \\
\hline$R / 170-I$ & impulzus & 170 & 25 & 23 & 11 & 2 & 3 & 4 & 7 & Bekapcsolva \\
\hline$R / 170-D I$ & duplaimpulzus & 170 & 25 & 28 & 12 & 2 & 2 & 5 & 7 & Bekapcsolva \\
\hline$D / 170-D C S$ & rövidzárlatos & 170 & 17 & 25 & 8 & 1 & 3 & 3 & 5 & Bekapcsolva \\
\hline$D / 170-I$ & impulzus & 170 & 24 & 19 & 12 & 2 & 2 & 5 & 5 & Bekapcsolva \\
\hline$D / 170-D I$ & duplaimpulzus & 170 & 24 & 18 & 10 & 2 & 2 & 5 & 5 & Bekapcsolva \\
\hline$D / 150-D C S-O N$ & durvacseppes & 150 & 17 & 36 & 8 & 2 & 3 & 3 & 4 & Bekapcsolva \\
\hline $\begin{array}{c}D / 150-D C S- \\
O F F 1 \_22 V\end{array}$ & durvacseppes & 150 & 22 & 27 & 10 & 2 & 3 & 4 & 4 & Kikapcsolva \\
\hline $\begin{array}{l}\text { D/150-DCS- } \\
\text { OFF2_24V }\end{array}$ & durvacseppes & 150 & 24 & 18 & 10 & 1 & 2 & 5 & 7 & Kikapcsolva \\
\hline
\end{tabular}

A vizsgálatok során készült felvételek a 2. ábrán láthatók.

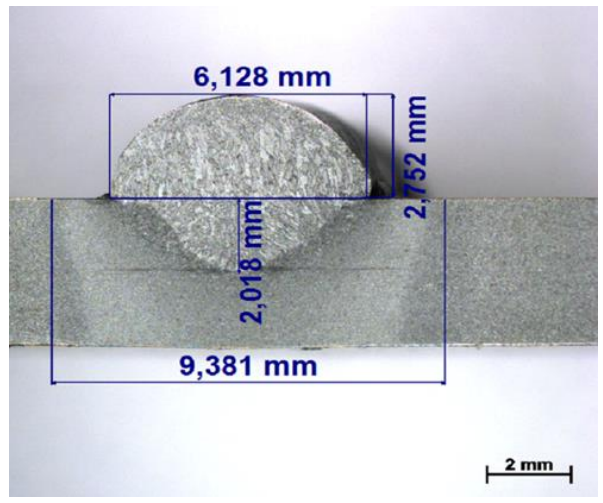

a) $R / 120-R Z$

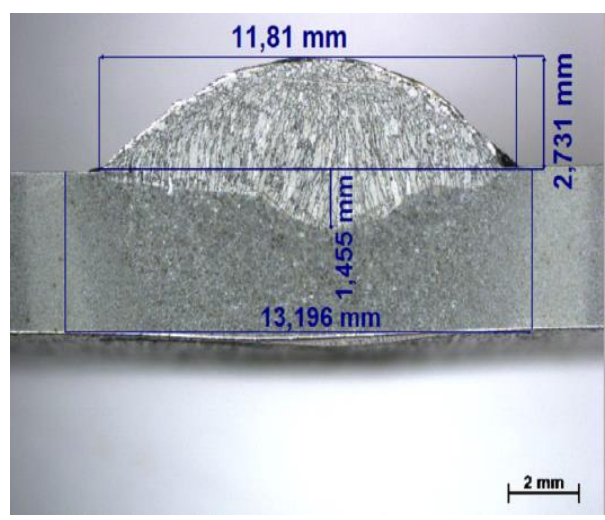

c) $R / 120-D I$

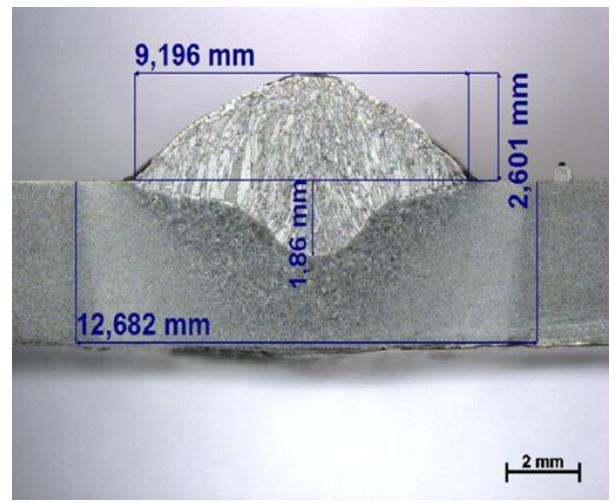

b) $R / 120-I$

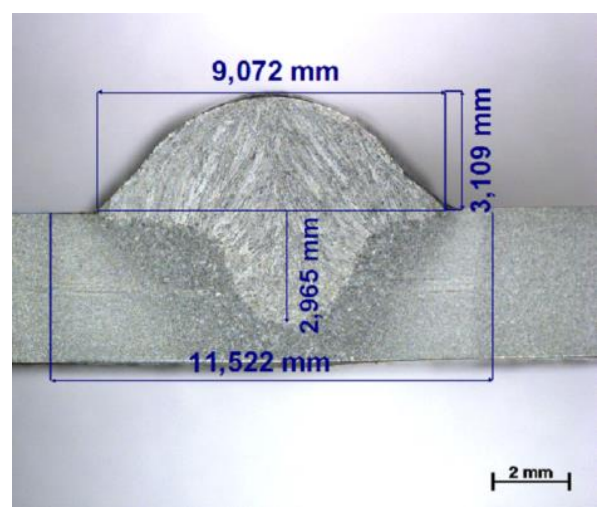

d) $R / 170-R Z$ 


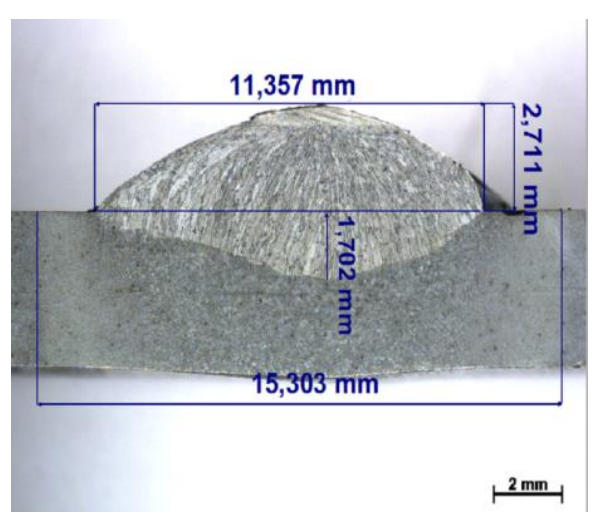

e) $R / 170-I$

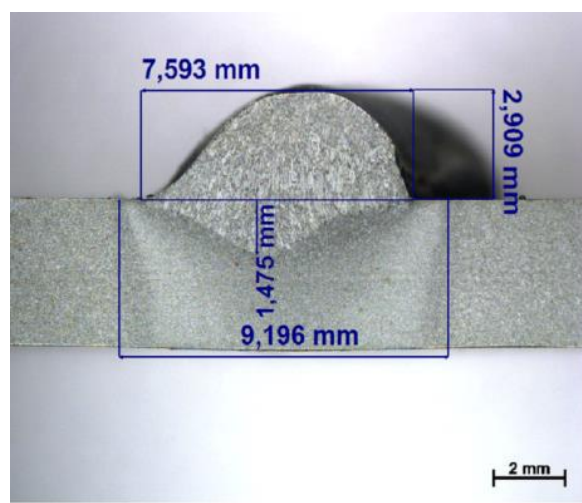

g) $D / 170-R Z$

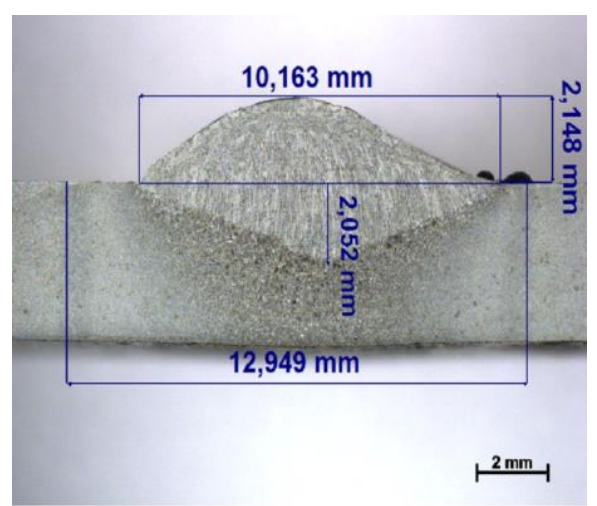

i) $\mathrm{D} / 170-D I$

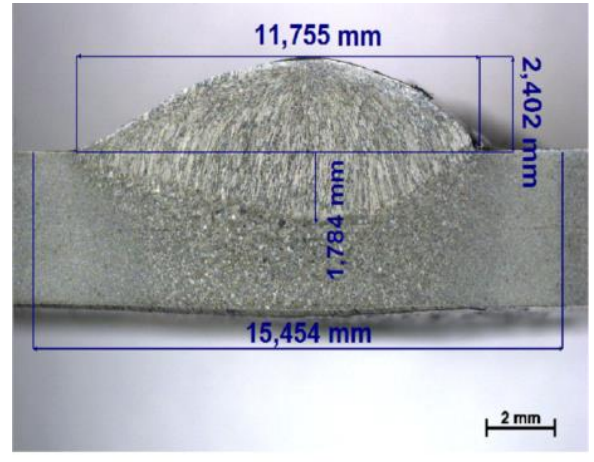

f) $R / 170-D I$

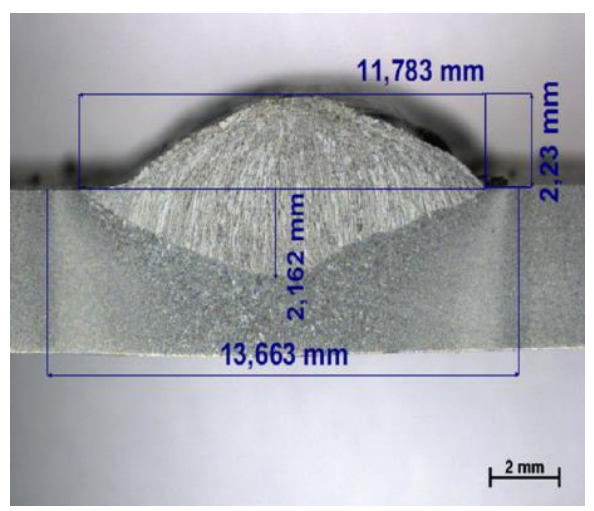

h) $D / 170-I$

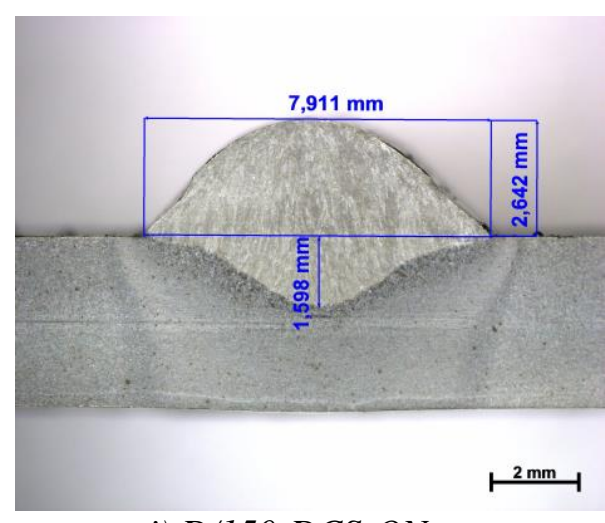

j) $\mathrm{D} / 150-\mathrm{DCS}-\mathrm{ON}$ 


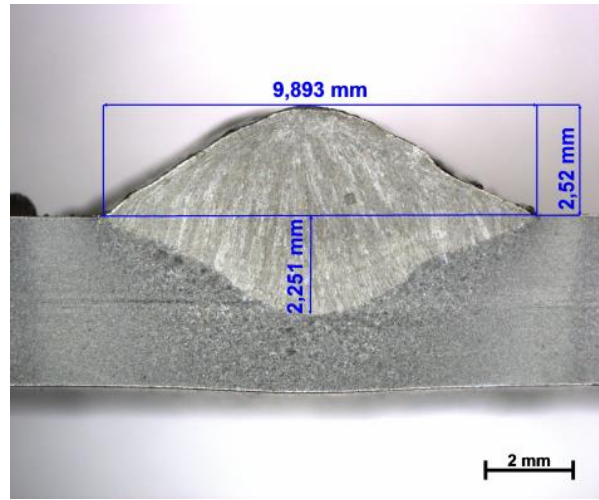

k) D/150-DCS-OFF1_22V

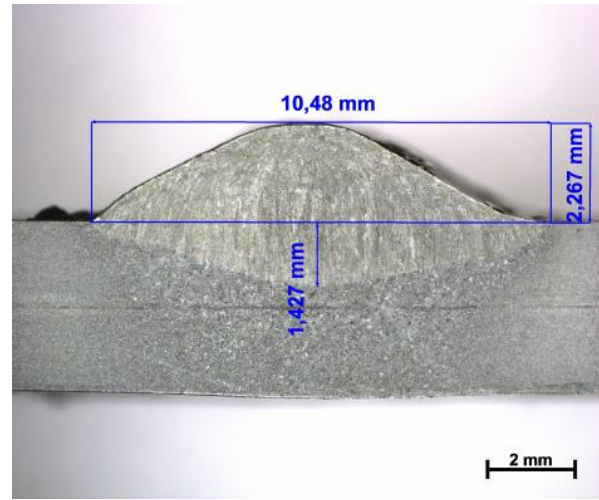

l) $\mathrm{D} / 150-\mathrm{DCS}$-OFF1_24V

2. ábra. Varratokról készitett makroszkópi felvételek (marószer: $2 \% \mathrm{HNO}_{3}, \mathrm{~N}: 8 x$ )

Az ívfeszültség és a varratszélesség között szoros összefüggés figyelhető meg. Növekvő ívfeszültség mellett a katódból kilépő elektronok csak a nagyobb távolságot megtéve érik el az anódot. Ez növeli annak esélyét, hogy negatív töltésủ részecskék még ionizálatlan gázatommal találkozzanak, valamint hogy a fellépő ütközések az oszlop harangformájú szóródását okozzák.

Ha egy diagramon (3. ábra) ábrázoljuk a beolvadási mélység és a varratszélesség értékeit a különböző anyagátviteli módok függvényében, azonosan berendezésen 120 és $170 \mathrm{~A}$ áramerősség mellett, látható, hogy nagyobb áramerősség mellett mindhárom jellemző méret értéke növekedett, ami megfelel a szakirodalmi adatoknak. Megfigyelhető volt továbbá, hogy a mért értékek impulzus, valamint duplaimpulzus anyagátviteli mód esetén 170 A alkalmazásával csak kismértékben változtak.

Mind a külső, mind a belső formatényező értéke növekedett (4. ábra) az áramerősség növelésével.

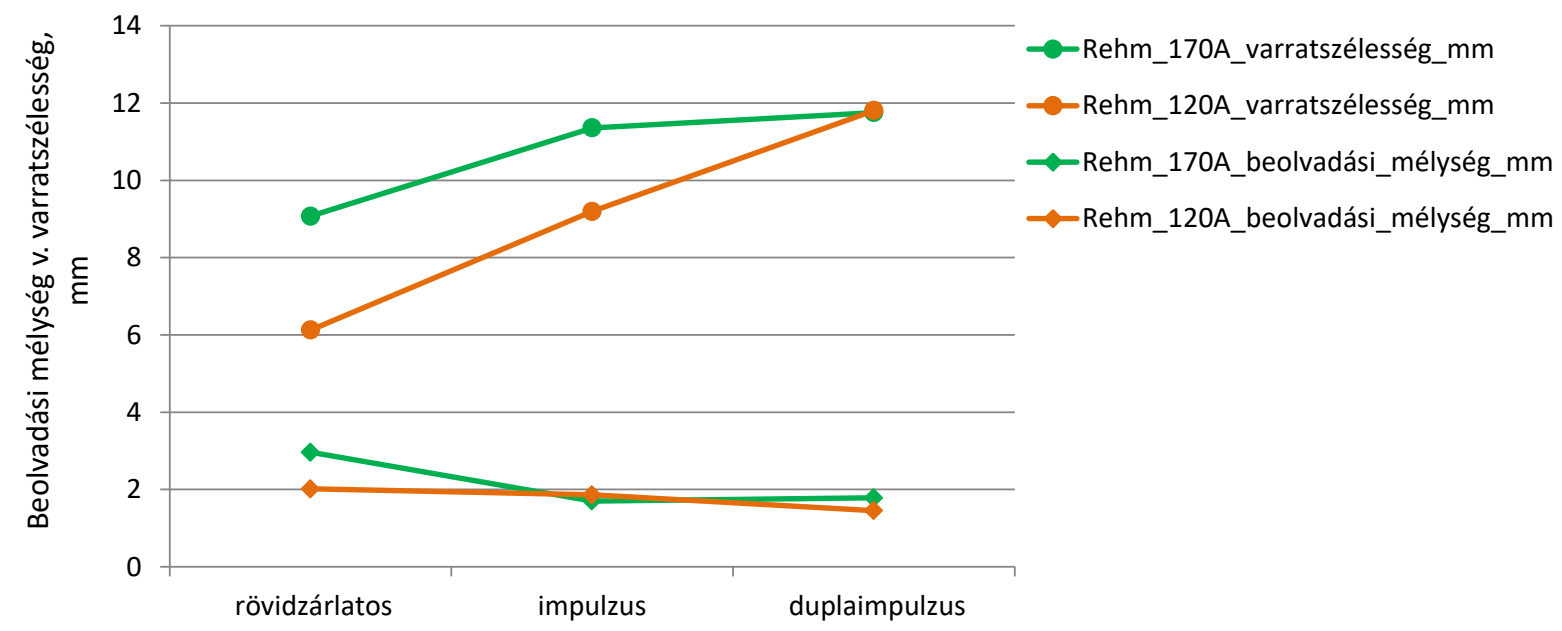

3. ábra. Különbözö áramerösséggel és anyagátviteli móddal készitett varratok geometriájának (beolvadási mélység és varratszélesség) összevetése azonos hegesztögép esetén 


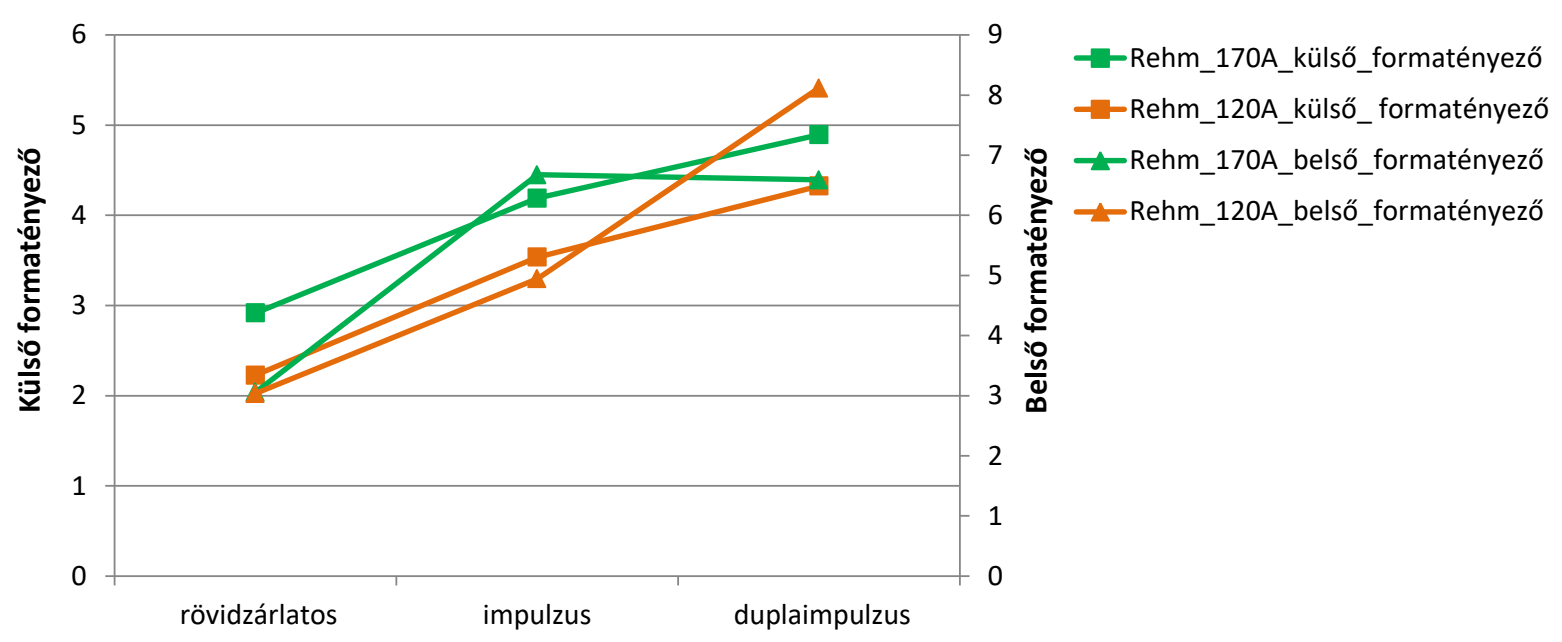

4. ábra. Különbözö áramerősséggel és anyagátviteli móddal készitett külső és belső formatényezőinek összevetése hegesztögép esetén

Ha összevetjük a két gépen azonos paraméterekkel és anyagátviteli módokkal készített kötéseket (5. ábra), láthatjuk, hogy anyagátviteli módtól függetlenül a Rehm gyártású gépen nagyobb volt a varratszélesség és kisebb a formatényező. A beolvadási mélység impulzus és duplaimpulzus esetén közel megegyezett.

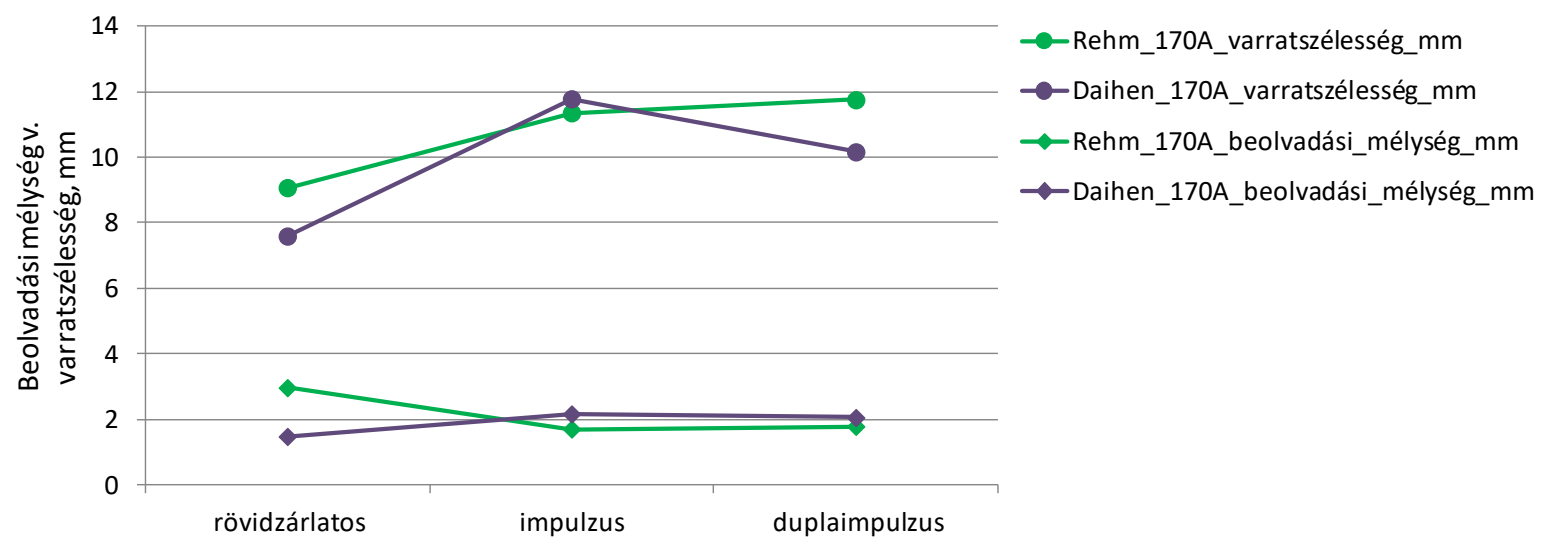

5. ábra. Különbözö berendezéssel, azonos paraméterek mellett készitett kötések geometriájának (beolvadási mélység és varratszélesség) összevetése

A Rehm gyártású gép esetében jól látható, hogy állandó áram mellett az üzemmódok változtatásával változtatásával a formatényező kedvezőbb lett (6. ábra). A Daihen gép esetében a viszont a legkedvezőbb belső formatényező értéket az impulzusos anyagvitel esetében mértük. Ebben az esetben az üzemmód megváltoztatása csökkentette a varratszélességet, a beolvadási mélység viszont nem változott. 


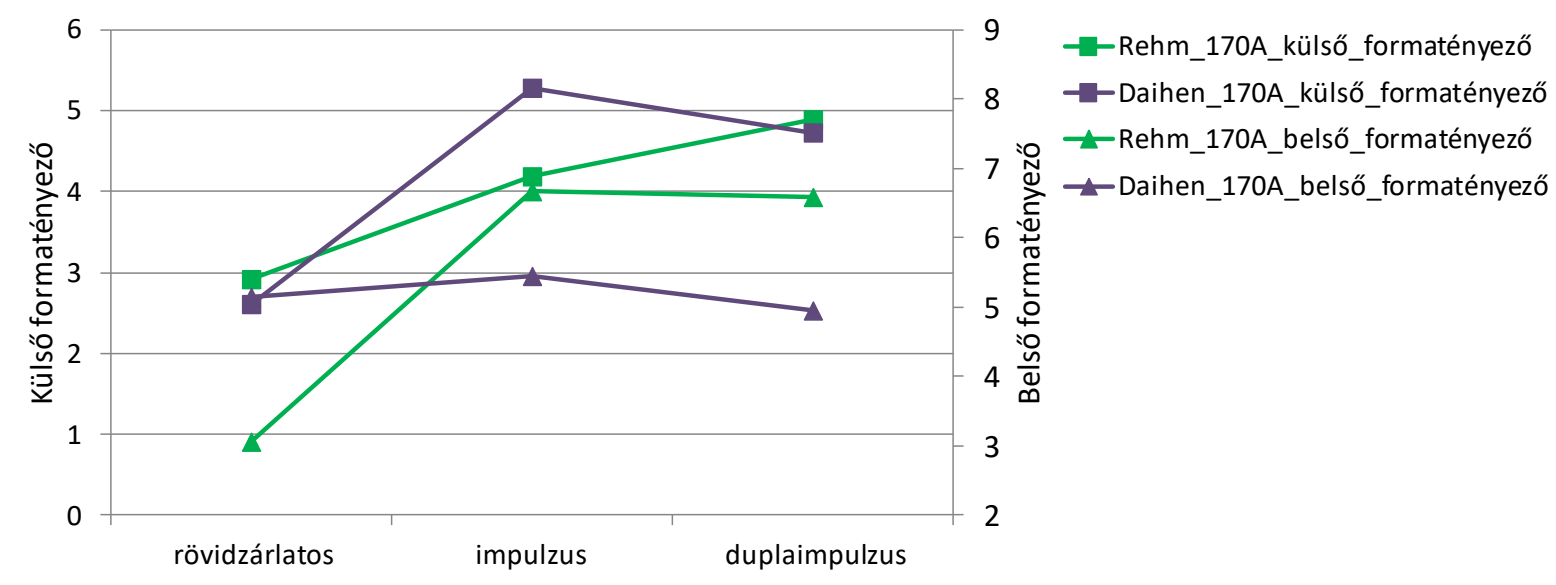

6. ábra. Különbözö berendezéssel, azonos paraméterek mellett készitett külsö és belsö formatényezöinek összevetése

Vizsgáltuk továbbá, hogy a szinergia ki- és bekapcsolása milyen mértékben módosítja a varratgeometriát. A vizsgálatokhoz a kötéseket $150 \mathrm{~A}$ áramerősséggel készítettük el, két esetben kikapcsoltuk a szinergiát és a feszültséget 22 és 24 V-ra állítottuk az eredeti 17 V-ról.

A feszültség változtatásával látható (7. ábra), hogy a beolvadási mélység általánosságban csökkent, míg a varrat szélessége növekedett. A feszültség kismértékü módosításával $(22 \mathrm{~V})$ a beolvadási mélység kismértékben növekedett az eredeti $17 \mathrm{~V}$-hoz képest és emellé kedvezőbb külső és belső formatényező is társult. Elmondható, hogy a szinergikus üzemmód kikapcsolásával és a feszültség kismértékü növelésével kedvezőbb varratalak érthető el [1].

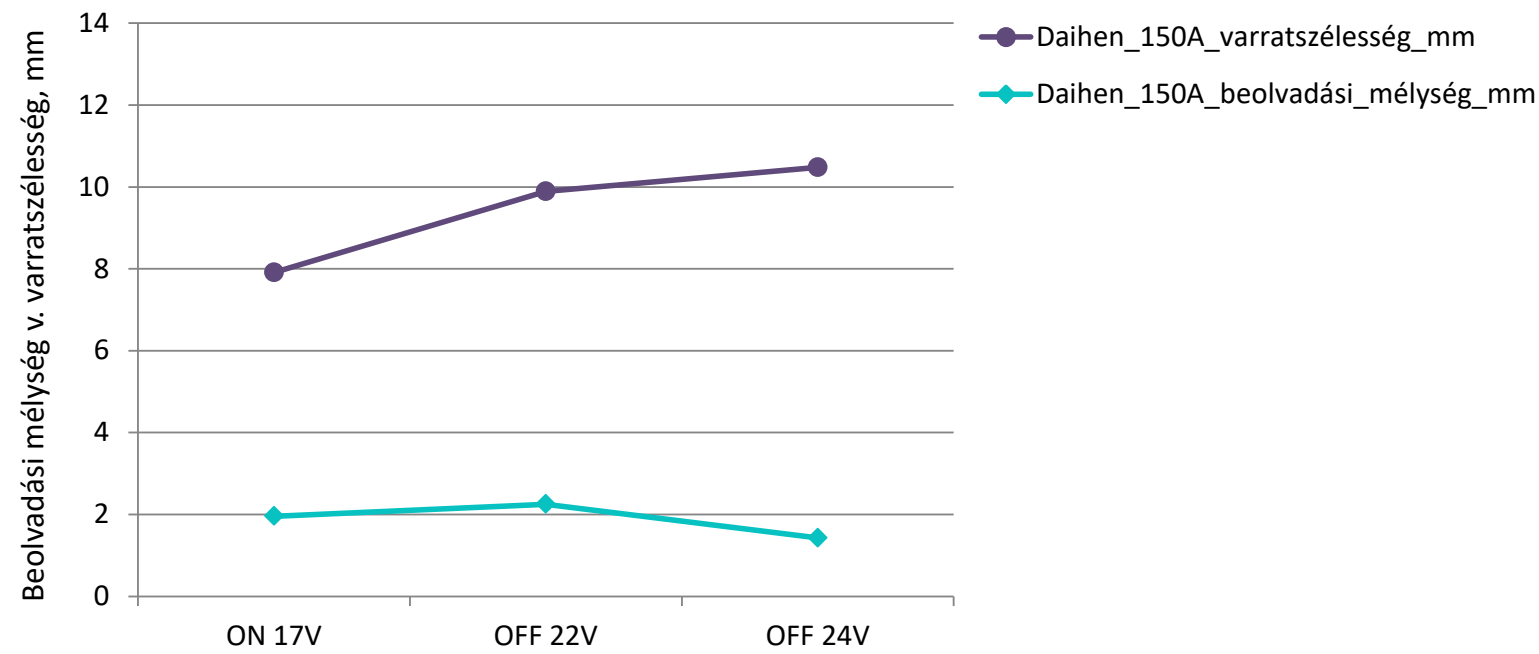

7. ábra. A szinergia hatása a varrat alakjára azonos hegesztőgép és áramerösség mellett ( $I=150$ A) 


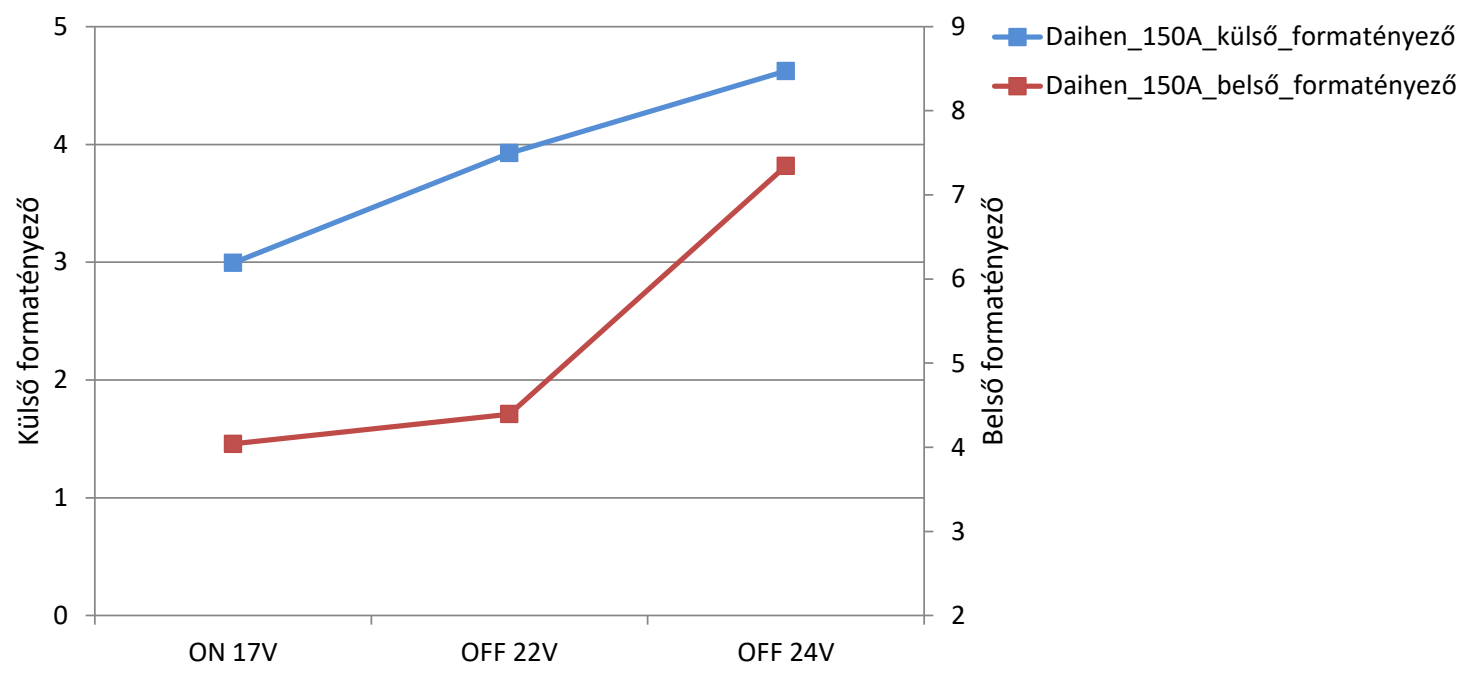

8. ábra. A szinergia hatása a külső és belsö formatényezőre azonos hegesztögép és áramerösség mellett $(I=150 \mathrm{~A})$

\section{4. Összefoglalás}

Munkánk során az ismert szabályozatlan cseppátmeneti formák mellett eltérő impulzus üzemmódokat felhasználva hegesztési kísérleteket végeztünk el, amelyekkel minőségbeli javulásokat tudunk elérni. A kapott eredményeket optikai mikroszkópos vizsgálatokkal elemeztük, összehasonlítva a különböző eljárásváltozatokat és megvizsgálva azt, hogy milyen minőségi és termelékenységi javulást érthetünk el használatukkal.

Az elvégzett kísérleti munka során az alábbi összefoglaló megállapításokat tehetjük:

- Az áramerősség növelésével mind a varrat beolvadási mélysége, szélessége, a külső és belső formatényező értéke nőtt azonos hegesztőgép esetén. Megfigyelhető volt továbbá, hogy a mért értékek impulzus, valamint duplaimpulzus anyagátviteli mód esetén 170 A alkalmazásával csak kismértékben változtak.

- A két különböző hegesztőgéppel végzett vizsgálatokból megállapítható, hogy a formatényező értéke azonos beállítások mellett nagyban függött az alkalmazott géptípustól.

- A szinergia be- illetve kikapcsolása ugyancsak hatással volt a varratalakra és bizonyos esetben a szinergia kikapcsolása és a feszültség kismértékü növelése kedvezően módosította a varratalakot, ugyanis a feszültség kismértékü módosításával a beolvadási mélység kismértékben növekedett az eredetihez képest és emellé kedvezőbb külső és belső formatényező is társult. Elmondható, hogy a szinergikus üzemmód kikapcsolásával és a feszültség kismértékü növelésével kedvezőbb varratalak érthető el.

\section{Köszönetnyilvánítás}

A cikkben ismertetett kutató munka az EFOP-3.6.1-16-2016-00011 jelü „Fiatalodó és Megújuló Egyetem - Innovativ Tudásváros - a Miskolci Egyetem intelligens szakosodást szolgáló intézményi 
fejlesztése" projekt részeként - a Széchenyi 2020 keretében - az Európai Unió támogatásával, az Európai Szociális Alap társfinanszírozásával valósul meg.

\section{Irodalom}

[1] Tóth, T., Májlinger, K.: Impulzustípusok hatása huzalelektródás védőgázas ívhegesztésnél vastaglemezek esetén, 28. Hegesztési Konferencia, Dunaújváros, 2016.

[2] Vágvölgyi, G., Dobránszky, J., Gyura, L., Reichardt, L.: A védőgáz és a volfrámelektródcsúcskialakítás hatása az asztenites acélok varratgeometriájára, BME

[3] Koncz, G., Májlinger, K.: Nem konvencionális volfrámelektóda-csúcskiképzés hatása a hegesztett varrat tulajdonságaira, OGÉT 2015 - XXIII. Nemzetközi Gépészeti Találkozó, 2015.

[4] Balogh, A., Dobosy, Á., Frigyik, G., Gáspár, M., Kuzsella, L., Lukács, J., Meilinger, Á., Nagy, Gy., Pósalaky, D., Prém, L., Török, I., Balogh, A. (szerk.), Lukács, J. (szerk.), Török, I. (szerk.) Hegeszthetőség és a hegesztett kötések tulajdonságai: Kutatások jármüipari acél és alumíniumötvözet anyagokon, Miskolc, Magyarország : Miskolci Egyetem, 2015, 324. p.

[5] Gáspár, M., Balogh, A.: Behaviour of mismatch welded joints when undermatching filler metal is used, Production Processes and Systems 2014, 7(1):63-76.

[6] Uher, G.: A védőgázas fogyóelektródás ívhegesztés korszerü eljárásváltozatainak összehasonlító elemzése, Diplomaterv, Miskolci Egyetem, 2020, 64. p. 